УДК: $330.322: 332.146 .2$

https://doi.org/10.52058/2708-7530-2021-10(16)-273-284

Борщук Свген Михайлович доктор економічних наук, професор,професор кафедри регіонального та місцевого розвитку, Навчально-науковий інститут державного управління, вул. Василя Сухомлинського, 16, Брюховичі, 79491, тел.: (0322) 34-65-68, e-mail: evhenborshuk@ gmail.com, https://orcid.org/0000-0001-8695-6588

Лисачок Алла Василівна аспірантка кафедри регіонального та місцевого розвитку, Навчально-науковий інститут державного управління, вул. Василя Сухомлинського, 16, Брюховичі, 79491, тел.: (0322) 34-65-68, e-mail: lysachok96@ukr.net, https://orcid.org/0000-0002-5716-487X

\title{
ТЕОРЕТИКО-ПРИКЛАДНІ ЗАСАДИ ФОРМУВАННЯ ІНВЕСТИЦЙНОӤ ПОЛІТИКИ СТАЛОГО РОЗВИТКУ
}

Анотація. Визначено, що стратегічним напрямком сучасного цивілізаційного розвитку $є$ сталий розвиток, формування якого обумовлено суттєвим загостренням проблем, пов'язаних з соціальною нерівністю, характером економічних процесів і їх впливом на довкілля тощо. Виокремлено роль ООН у формуванні глобальних процесів переходу світової економіки на принципи сталого розвитку. В роботі сутність сталого розвитку авторами трактується як поєднання економічного зростання із забезпеченням соціальної захищеності населення та мінімізацією негативного впливу на навколишнє середовище. Досліджено теоретико-прикладні засади формування інвестиційної політики в умовах переходу функціонування економіки на принципи сталого розвитку.

Сталий розвиток на будь-якому рівні можливий лише за умов наявності відповідних інвестиційних ресурсів і доведена необхідність формування системи інвестиційних ресурсів, ефективне залучення, акумулювання та використання інвестицій, що є об'єктивною передумовою досягнення цілей сталого розвитку. Авторами проаналізовано існуючі трактування поняття «інвестиційна політика сталого розвитку. Узагальнення існуючих підходів до визначення категорії «інвестиційна політика» дозволяє трактувати інвестиційну політику як сукупність дій економічних агентів із забезпечення умов простого і розширеного відтворення капітальних ресурсів у регіоні або в державі в цілому. Сутність інвестиційної політики сталого розвитку полягає в забезпеченні відтворення основних фондів виробничих i невиробничих галузей, їх розширенні i модернізації. В роботі виокремлено низку важливих факторів, що сприяють формуванню привабливого для іноземних інвесторів інвестиційного клімату в Україні, який сприяє розширенню інвестиційних зв'язків, стимулюванню приросту іноземного капіталу, який можна буде використати для досягнення 
цілей сталого розвитку.

Ключові слова: розвиток, стратегія, сталий розвиток, інвестиції, інвестиційна політика.

Borshchuk Yevgen Mykhailovych Doctor of Economic Sciences, Professor, Professor at the of regional and local development, Vasyl Sukhomlinsky St., 16, Bryukhovichi, 79491, tel.: (0322) 34-65-68, e-mail: evhenborshuk@gmail.com, https://orcid.org/0000-0001-8695-6588

Lysachok Alla Vasylivna Postgraduate Student at the Department of regional and local development, e-mail:lysachok96@ukr.net, Vasyl Sukhomlinsky St., 16, Bryukhovichi, 79491, tel.: (0322) 34-65-68, https://orcid.org/000-0002-5716-487X

\section{THEORETICAL AND APPLIED FOUNDATIONS FORMATION SUSTAINABLE DEVELOPMENT INVESTMENT POLICY}

Abstract. It has been established that the strategic direction of modern civilization development is sustainable development, the formation of which is caused by a significant aggravation of problems related to social inequality, the nature of economic processes and their impact on the environment, etc. The role of the United Nations in the formation of global processes of transition of the world economy to the principles of sustainable development is highlighted. In the article, the essence of sustainable development is interpreted by the authors as a combination of economic growth with ensuring social protection of the population and minimizing the negative impact on the environment. The theoretical-applied bases for investment policy-making in the context of the transition of the economy to the principles of sustainable development have been studied.

Sustainable development at any level is possible only if the appropriate investment resources are available, and it has been proved that there is a need for the formation of a system of investment resources. The objective precondition for achieving sustainable development goals is the effective attraction, accumulation and use of investment. The authors analyzed the existing interpretations of the concept of "investment policy of sustainable development". The generalization of existing approaches to the definition of the "investment policy" category allows to interpret the investment policy as a set of economic agents' actions to ensure the conditions of simple and expanded reproduction of capital resources in the regions or in the country as a whole. The essence of investment policy for sustainable development is to ensure the reproduction, expansion, and modernization of capital stock of productive and non-productive sectors. The article identifies a number of important factors contributing to the creation of an attractive investment climate for foreign investors in Ukraine, which contributes to the expansion of investment links and the stimulation of foreign capital growth, that can be used to achieve the Sustainable Development Goals. 
Keywords: development, strategy, sustainable development, investments, investment policy.

Постановка проблеми. Цілі сталого розвитку (ЦСР), затверджені в документах ООН і які повинні бути адаптовані до національних особливостей соціально-економічного розвитку кожної країни, обумовлюють необхідність формування системи відповідних ресурсів для досягнення поставлених завдань. За своєю суттю сталий розвиток спрямований на забезпечення збалансованості екологічних, соціальних і виробничих аспектів цивілізаційного розвитку. Як зазначає Генеральний секретар ООН А. Гутерреш, стратегія сталого розвитку в умовах пандемії COVID-19, повинна бути зосереджена на формуванні більш рівноправних, інклюзивних i сталих економік i суспільств, які будуть стабільними в умовах пандемії, зміни клімату і появи інших глобальних проблем. Це обумовлює необхідність пріоритетного формування відповідної системи інвестицій для забезпечення сталого розвитку, наукового обгрунтування підходів до формування інвестиційної політики, визначення стратегічних напрямків соціально орієнтованої інвестиційної діяльності. Стратегічною метою інвестиційної політики повинно стати максимально ефективне використання інвестиційного потенціалу для досягнення ЦСР.

Аналіз останніх досліджень та публікацій. Різні аспекти формування інвестиційних процесів в умовах переходу функціонування соціальноекономічних систем на принципи сталого розвитку, дослідження основних напрямків взаємозв'язку інвестицій та проблем соціально-економічного розвитку, вже тривалий час знаходяться в центрі уваги вітчизняних дослідників: Білоруса О.Г., Мацейко Ю.М., Данилишина Б.М., Корецького М.Х., Дація О.І., Кузьміна О. Є., Князь С.В., Мельник Л.І. [1-3]. Визнаючи важливість результатів провідних учених стосовно проблем залучення інвестицій в соціальноекономічний розвиток, необхідно зазначити недостатність уваги дослідників до аналізу особливостей формування інноваційно-інвестиційної політики сталого розвитку, недостатність уваги до розробки механізмів залучення і використання інвестиційного потенціалу для досягнення саме цілей сталого розвитку.

Виділення невирішених раніше частин загальної проблеми. Проблема формування інвестиційної політики обумовлюється також недостатньою науково-методичною розробкою проблем інвестиційної політики стосовно сталого розвитку і пошуку шляхів ефективного використання інвестиційного потенціалу національної економіки. Досить фрагментарно досліджуються теоретичні питання, що стосуються економічного обгрунтування інвестицій, поліпшення інвестиційного клімату, впливу інвестиційних процесів на фінансове забезпечення сталого розвитку, безпека інвестиційних процесів сталого розвитку. Все це в сукупності обумовлює необхідність формування наукових основ інвестиційної політики головним завданням якої повинно стати досягнення як основи забезпечення Цілей сталого соціально-економічного розвитку на XXI 
століття.

Метою статті $\epsilon$ системний аналіз підходів до формування i реалізації інвестиційної політики сталого розвитку в сучасних умовах.

Виклад основного матеріалу. Впродовж другої половини XX cт. i на початку XXI ст. відбувся активний пошук нової моделі цивілізаційного розвитку в результаті чого була запропонована модель сталого, яка базується на поєднанні економічного зростання, забезпечення соціальної захищеності населення та мінімізації негативного впливу економіко-техногенних процесів на довкілля. В самому загальному вигляді концепція сталого розвитку була офіційно сформульована в доповіді «Наше спільне майбутнє» (Our Common Future), підготовленому Міжнародною комісією ООН 3 навколишнього середовища $\mathrm{i}$ розвитку в 1987 році [4]. Згідно визначенням Комісії сталий розвиток $\epsilon$ гармонійним соціально-економічним розвитком, який, задовольняє сучасні покоління, не ставить під загрозу здатність майбутніх поколінь задовольняти свої власні потреби. В умовах переходу функціонування соціально-економічних систем традиційний підхід до ведення бізнесу поступово починає втрачати свою силу - все більше світових компаній фінансового i не фінансового сектора впроваджують принципи сталого розвитку в свої бізнес-моделі.

Сталий розвиток на будь-якому рівні можливий лише за умов наявності відповідних інвестиційних ресурсів i необхідність формування системи інвестиційних ресурсів, ефективне залучення, акумулювання та використання інвестицій є об'єктивною передумовою досягнення ЦСР. На сучасному етапі для будь-якої країни першочерговим завданням постає пошук джерел інвестицій, які б забезпечили подальший сталий розвиток будь-якої держави. За деякими підрахунками, порядок величини потреб в додаткових інвестиціях для сценаріїв сталого розвитку оцінюється в кілька трильйонів доларів США в рік. Приблизна оцінка витрат лише на викорінення крайньої бідності у всіх країнах (вимірюється витратами на підвищення доходів найбідніших груп населення до рівня в 1,25 дол. США в день) складає близько 66 млрд. дол. США на рік. Оцінки щорічних інвестиційних потреб в сфері інфраструктур сектора водопостачання, сільського господарства, електрозв'язку, енергетики, транспорту, будівництва і лісового господарства - складають близько 5-7 трлн. дол. США по всьому світу. За оцінками комітету для ліквідації голоду до 2025 року необхідно 50,2 млрд. дол. США на рік; 37 млрд. дол. США - для досягнення загального медико-санітарного обслуговування;- 42 млрд. дол. США для досягнення загальної початкової освіти і розширення доступу до нижчих щаблях середньої освіти. В умовах поширення пандемії у всіх країнах виникає загострення проблем, пов'язаних 3 охороною здоров'я, соціальною нерівністю, $з$ впливом економічної діяльності на зміну клімату, які вимагають прийняття невідкладних заходів та пріоритетного виділення інвестицій для забезпечення сталого розвитку $[5,6]$. Все це обумовлює формування ефективної, науково обгрунтованої політики інвестування сталого розвитку. 
Перш ніж визначатись 3 поняттям «інвестиційна політика сталого розвитку» проаналізуємо існуючі підходи до сучасного трактування понять «інвестиції» та «інвестиційна політика». Узагальнюючи підходи різних авторів Музиченко Т. пропонує розглядати інвестиційну діяльність як послідовну сукупність дій іiі суб'єктів щодо здійснення інвестицій з метою одержання прибутку. Кожна держава, як суб'єкт інвестиційної діяльності, в своєму законодавстві визначає правові, економічні та соціальні умови цієї діяльності. У вужчому тлумаченні цього поняття застосовують термін «інвестиційний процес». Інвестиційні процеси в державі з ринковою економікою і при адміністративно регулюючій системі господарювання суттєво відрізняються. Ключовим моментом у забезпеченні інвестиційних процесів економічного розвитку держави чи регіону $\epsilon$ визначення відповідного механізму регулювання інвестиційної діяльності, який забезпечує формування інвестиційних потоків, що сприятимуть максимальному ефекту від раціонального управління ними. Серед сформованого різноманіття підходів до дослідження інвестиційних механізмів автор виокремлює такі основні підходи:

- дослідження інвестиційної діяльності з погляду елементів інвестиційного процесу;

- дослідження інвестиційної діяльності з погляду суб'єктів інвестиційного процесу (населення, держави, інвестиційних інститутів, об'єктів інвестування) і механізмів формування ними джерел інвестиційних коштів;

- дослідження інвестиційної діяльності стосовно інструментів і об'єктів вкладення інвестиційного капіталу [7, с. 163-164].

В загальному, до важливих умов формування інвестиційного процесу в ринковій економіці відносять:

- наявність значного інвестиційного капіталу 3 диверсифікованою за формами власності структурою, що характеризується домінуванням приватного інвестиційного капіталу;

- багатоманітність суб'єктів інвестиційної діяльності різної організаційноправової форми та інституціональної організації;

- наявність мережі інвестиційних посередників, що сприяють реалізації інвестиційного попиту та пропозиції;

- розподіл інвестиційного капіталу за об'єктами інвестування у відповідності 3 економічними критеріями оцінки привабливості інвестицій через механізм інвестиційного ринку;

- наявність розвинутого багато сегментного ринку об’єктів інвестиційної діяльності, що виступають у формі інвестиційних товарів [8].

Загальновизнано, що інвестиційний процес розпочинається 3 мотивації інвестиційної діяльності. Основним мотивом такої діяльності є надлишок певних коштів у суб'єкта господарювання або приватної особи, яких не влаштовують відсотки за банківськими депозитами. Інвестор, що $\epsilon$ власником цих нагромаджень (збережень), прагне придбати на інвестиційному ринку фінансові 
активи або інвестиційні товари (реальні активи), тобто здійснити інвестиції [9]. Водночас, віддача від інвестицій великою мірою залежить від механізму їх регулювання, який являє собою сукупність взаємозалежних інструментів і умов, регулювання яких веде до зміни обсягів і напрямків обсягу інвестиційних потоків [10]. В цілому, ефективність використання інвестиційних коштів визначається наявністю адекватної інвестиційної політики. В основі визначення поняття «інвестиційна політика сталого розвитку» лежить поняття «інвестиційна політика». Узагальнення існуючих підходів до визначення категорії «інвестиційна політика» дозволяє трактувати інвестиційну політику як сукупність дій економічних агентів із забезпечення умов простого і розширеного відтворення капітальних ресурсів у регіоні або в державі в цілому. Сутність інвестиційної політики полягає в забезпеченні відтворення основних фондів виробничих i невиробничих галузей, їх розширенні i модернізації $[11,12]$. Зокрема, П. Сокуренко, О. Кришан визначають інвестиційну політику як комплекс заходів і перспектив розвитку інвестиційної діяльності для залучення інвестиційного потенціалу до процесу відтворення, створення оптимальних умов для вкладення інвестицій, забезпечення стійкого соціально-економічного розвитку країни [13].

В загальному, інвестиції $€$ однією 3 важливих чинників, які відіграють визначальну роль в активізації структурних перетворень в економіці, в економічному зростанню, стабільному функціонуванні підприємств. В сучасних умовах переходу функціонування соціально-економічних систем на принципи сталого розвитку інвестиційна політика. набуває особливого пріоритету залучення інвестиційних ресурсів сприяє досягненню цілей сталого розвитку, підвищенню ефективності виробництва, забезпеченню соціально-економічної стабільності та вирішенню екологічних проблем.. В цілому, інвестиції є головним інструментом, за допомогою якого зростає соціально-економічний потенціал сталого розвитку будь-якої держави [14-16].

За своїм характером, інвестування являє собою економічний процес, суть якого полягає в направлені вільних фінансових активів в розвиток конкретних економічних об'єктів на вирішення певних соціально-економічних проблем. В умовах переходу на принципи сталого розвитку появляються нові критерії інвестування, які обумовлені ЦСР. Сталий розвиток спрямований на системне вирішення сучасних проблем цивілізаційного розвитку: досягнення економічного зростання, забезпечення справедливого розподілу його результатів, створення умов для реалізації людського потенціалу без виснаження, деградації i забруднення при цьому довкілля для сучасного і майбутніх поколінь[17, с. 43].

Складовими інвестиційної політики сталого розвитку, як i для економічного розвитку взагалі, $\epsilon$ :

- рівень розвитку продуктивних сил в країні;

- рівень розвитку інвестиційного ринку;

- рівень розвитку фінансово-кредитної системи країни; 
- законодавчо-нормативна база держави;

- умови інвестиційної діяльності для іноземного інвестора;

- рівень інвестиційної активності населення [18, с. 127].

До головних проблем формування інвестиційного потенціалу сталого розвитку в Україні можна віднести:

- вдосконалення нормативно-правової бази в інвестиційній сфері;

- визначення пріоритетних сфер економіки ля інвестування та надання їм пільг;

- захист прав інвесторів на державному рівні;

- сприяння розвитку науки, науково-технічної і інноваційної діяльності;

- створення технопарків з новітніми технологіями;

- активна участь у міжнародних інвестиційних проектах;

- робота 3 міжнародними рейтинговими агентствами;

- проведення маркетингових досліджень в області залучення до країни інвестицій;

- моніторинг світових інвестиційних потоків і аналітичних досліджень;

- запрошення до України фахівців світового рівня для розробки стратегій залучення інвестицій;

- закріплення макроекономічної стабілізації і перехід Національного Банку України до політики низьких процентних ставок;

- проведення структурних реформ в економіці, включаючи податкову реформу, надання податкових пільг на розвиток інноваційних галузей;

- здійснення інституціональних реформ (антикорупційної реформи, модернізація адміністративної та судової систем, реформи правоохоронних органів) та наближення інституційного середовища на внутрішньому ринку України до європейських вимог шляхом імплементації положень Угоди про асоціацію між Україною та ЄС [19-21].

На думку провідних науковців сьогодні в Україні існує низка факторів, що сприяють формуванню привабливого для іноземних інвесторів інвестиційного клімату, який сприяє розширенню інвестиційних зв'язків, стимулюванню приросту іноземного капіталу, який можна буде використати для досягнення ЦСР:

- великий та майже конкуренто необмежений внутрішній ринок з більшості товарних позицій;

- розташування основних транспортних шляхів між Європою та Азією;

- розвинена інфраструктура (наявність портів, мостів, летовищ, складів, систем зв'язку, водопостачання);

- дешева, але кваліфікована робоча сила;

- науковий потенціал та ін. [22].

У 1992 році, закриваючи Всесвітню конференцію з довкілля і розвитку в Ріоде-Жанейро, іiі генеральний секретар М. Стронг виокремив центральну проблему у формуванні сталого розвитку - перехід від економічної до еколого-економічної 
системи (ЕEC). 3 позицій економічної теорії цей перехід обумовлений необхідністю прийняття нової макроекологічної парадигми: економіка повинна функціонувати в межах законів економіки природи. В цілому, функціонування EEC повинне бути спрямоване на задоволення суспільних потреб, які можна згрупувати в дві головні групи: соціально-економічні і екологічні. Задоволення соціально-економічних потреб відбувається благами природно-трудового походження, виробництво яких формується суспільством на основі існуючих природних і трудових ресурсів. Екологічні потреби задовольняються в процесі взаємодії людей 3 оточуючим природним середовищем i вони обумовлюють певні вимоги до якості оточуючого природного середовища. В цілому, базовими структурними елементами ЕEC $\epsilon$ соціальна, виробнича i екологічна підсистеми [23].

3 позицій системного аналізу при досліджені особливостей процесів формування інвестиційного клімату в умовах переходу до моделі ЕЕС необхідно дотримуватись наступних вимог. По-перше, система повинна враховувати всі причинно спадкові і існуючі замкнуті контури прямих і зворотних зв'язків між їі головними підсистемами. По - друге, для кожної конкретної підсистеми і ЕЕС в цілому, повинна бути визначена сукупність формальних i неформальних критеріїв їх сталого функціонування. По - третє, необхідно враховувати динамізм взаємодії головних підсистем в процесі функціонування ЕЕС.

На нашу думку, в основі формування інвестиційної політики сталого розвитку повинен бути стратегічний підхід запропонований ООН і який полягає в наступному:

- стратегії сталого розвитку здійснюються на національному рівні. Однак національні зусилля повинні доповнюватись міжнародною державною підтримкою, в міру необхідності, і сприятливою міжнародною обстановкою;

- ефективні державні інститути та політичні курси і ефективне управління відіграють головну роль в забезпеченні ефективного використання ресурсів і в вивільненні додаткових засобів для цілей сталого розвитку;

- для задоволення потреб у фінансуванні сталого розвитку необхідна оптимізація вкладу всіх потоків, включаючи державні, приватні, внутрішні i міжнародні. Необхідно враховувати специфіку кожного виду фінансування, важливо забезпечити максимальний синергізм всіх видів інвестицій;

- максимізація впливу міжнародних державних фінансів відіграє кардинальну роль в країнах, в яких потреби є найбільшими, а можливості для мобілізації ресурсів - найменшими. Використання фінансових інструментів i їх пільговий характер повинні відповідати рівню розвитку кожної країни, їх конкретним умов, потенціалом і можливостями;

- всебічне врахування критеріїв сталого розвитку в національних стратегіях фінансування, які повинні враховувати економічні, соціальні та екологічні компоненти сталого розвитку;

- використання синергізму в економічних, екологічних та соціальних 
компонентах інвестиційних процесів сталого розвитку. Різні цілі сталого розвитку нерідко частково збігаються, тому інвестування має плануватись так, щоб використовувати синергізм і підтримувати узгодженість політики в галузі сталого розвитку одночасно 3 урахуванням потенційних компромісів. Таким чином, інструменти фінансуванням можуть використовуватися для одночасного досягнення кількох національних стратегій сталого розвитку.

У доповіді Міжурядового комітету експертів по фінансуванню сталого розвитку виокремлено головні потреби, фінансування яких забезпечить перехід на принципи сталого розвитку [24]:

- базові потреби, пов'язані з викоріненням бідності та голоду, поліпшенням охорони здоров'я та освіти, забезпеченням доступу до дешевих джерел енергії і заохоченням гендерної рівності;

- національні потреби щодо фінансування інвестицій на цілі сталого розвитку, таких як інфраструктура, розвиток сільських районів, адаптація до зміни клімату і розвиток з урахуванням зміни клімату, так само як і енергетика;

- глобальні суспільні блага, включаючи охорону глобального навколишнього середовища і боротьбу зі зміною клімату та його наслідками, а також в інших областях.

У Доповіді про ЦСР за 2019 рік наголошується на взаємозалежності проблем бідності, соціальної нерівності, зміни клімату та інших глобальних проблем, що обумовлює особливості формування інвестиційних процесів сталого розвитку. Так, наприклад, боротьба зі зміною клімату вимагає переходу на екологічно чисті джерела енергії, зміни наших моделей виробництва та споживання. Інвестування у раціональні підходи до ведення сільського господарства спроможне здійснити вагомий внесок в боротьбу як з голодом, так і з бідністю, оскільки близько 80 відсотків людей, що живуть в умовах крайньої бідності, — це мешканці сільських районів [25].

Висновки. Таким чином можна стверджувати, що інвестиційна політика $\epsilon$ важливим чинником переходу функціонування національної економічної системи на принципи сталого розвитку. Інвестиції сталого розвитку необхідно розглядати як інвестиції, спрямовані на досягнення ЦСР i кінцевим результатом інвестиційного процесу повинно стати вирішення соціальних, екологічних i економічних проблем в сучасних нестабільних умовах функціонування ЕЕС. Головними напрямками формування інвестиційного клімату для сталого розвитку України є удосконалення законодавчих і нормативно-правових засад управління інвестиційними процесами в умовах децентралізації державного управління соціально-економічним розвитком. В цілому, інвестування в національну економічну систему повинно бути спрямоване на розвиток пріоритетних галузей народного господарства, стратегічних виробництв, депресивних територій i конкурентних та імпортозамінних товарів і продукції.

Особливості інвестиційних процесів сталого розвитку обумовлюються глобальними цілями, завданнями і принципами сталого розвитку. На їх основі 
повинні визначатись найістотніші завдання, на вирішення яких повинна бути спрямована інвестиційна політика сталого розвитку будь-якої країни.

\section{Лimepamypa:}

1. Білорус О. Г., Мацейко Ю. М. Глобальний сталий розвиток : монографія. Київ : КНЕУ, 2006. $488 \mathrm{c.}$

2. Данилишин Б. М., Корецький М. Х., Дацій О.I. Інвестиційна політика в Україні : монографія. Донецьк : «Юго-Восток, ЛТД», 2006. 292 с.

3. Кузьмін О. Є., Князь С.В., Мельник Л.І. Управління інноваційним процесом на підприємствах: проблеми і шляхи їх розв'язання. Економічний вісник Національного технічного університету України «Киӥвський політехнічний інститут». 2005. № 2. С. 371-382.

4. Word Commission on Environment and Development «Our Common Future» / Ed.G. Bruntland. Oxford : Oxford Univ. Press, 1987. 400 p.

5. Осуществление реформы СР ООН и инновационное финансирование ЦУР. URL : https://www.unfpa.org/sites /default/ files/admin-resource/RU_AR.pdf (дата звернення: 30.08.2021).

6. Доклад о мировых инвестициях, ЮНКТАД (2014). URL : http://unctad.org/en/ pages/ PressRelease.aspx? OriginalVersionID=194 (дата звернення: 26.08.2021).

7. Музиченко Т. О. Інвестииії та інвестиційна діяльність: понятійний апарат. Сталий розвиток економіки. 2014. № 3. C. 161-167. URL : http://nbuv. gov.ua/ UJRN/ sre_2014_3_28 (дата звернення: 29.08.2021).

8. Борщ Л. М., Герасимова. С.В. Інвестування: теорія і практика : навч. посібник. Київ : Знання, 2007. 685 с.

9. Губський Б. В. Інвестиційні процеси в глобальному середовищі. Київ : Наукова думка, 1997. 109 с.

10. Фінансовий словник-довідник /ред. М.Я. Дем'яненко. Київ : IAE УААН, 2003. 555 с.

11. Лановий В., Дубровський К. Інвестиції та розвиток. Київ : Центр ринкових реформ, 2002. $86 \mathrm{c}$.

12. Музиченко А. С. Державне регулювання інвестиційної діяльності : монографія. Київ: Науковий світ, 2001. 345 с.

13. Сокуренко П. І., О. Ф. Кришан. Інвестиційна політика як ефективна форма управління ухваленням інвестиційних рішень. Європейський вектор економічного розвитку. 2010. № 1 (8). С. 208-214.

14. Мартиненко В. Ф. Формування інвестиційної моделі розвитку України: методологічний аспект. Вісник Української Академії державного управління при Президентові України. 2003. № 3. С. 172-179.

15. Коюда О. П., Лепейко О. П., Коюда В. О., Гриньова В. М.. Інвестування. К. : Знання, 2008. $452 \mathrm{c}$.

16. Борщ Л. М., Герасимова С.В. Інвестування: теорія і практика. Київ : Знання, 2007. 685 с.

17. Оробець I. В. Практика впровадження концепції сталого розвитку в управлінні підприємствами. Формування ринкової економіки в Україні: зб. наук. пращь. Львів: ЛНУ ім. І. Франка, 2013. Вип. 29. Ч. 2. С. 43-48,

18. Бланк И.А. Инвестиционный менеджмент : учеб. курс. Киев : ИТЕМ ЛТД, 1995. 448 с.

19. Онопрієнко О. Д. Проблеми та шляхи формування сприятливого інвестиційного клімату в Україні в сучасних умовах. Стратегія розвитку Украӥни. 2015. № 2. С. 62-66, с. 64;

20. Бурлака Н.І. Розвиток інвестиційної діяльності підприємств України. Інвестиції: практика та досвід. 2019. № 8. С. 37-44.

21. Михайленко О. Г., Красникова Н. А. Вплив іноземних інвестицій на розвиток економіки України в умовах глобалізації. Ефективна економіка. 2020. № 7. URL: http://www.economy. nayka. com. ua/ ?op=1\&z=8046. (дата звернення: 22.08.2021). 
22. Маркевич К. Хто і як інвестує в Україну. URL : http://razumkov.org.ua/statti/khto-i-iakinvestuie-v-ukrainu. (дата звернення: 30.08.2021).

23. Загорський В.С. Концептуальні основи формування системи управління сталим розвитком еколого-економічних систем : монографія. Львів : ЛРІДУ НАДУ, 2018. 336 с.

24. Доклад Межправительственного комитета экспертов по финансированию устойчивого развития. URL: https: //www.un.org/esa/ffd/wp-content/uploads/2015/03/ ICESDF_Ru.pdf. (дата звернення: 30.08.2021).

25. Доклад о Целях в области устойчивого развития, 2019 год. URL: https://reliefweb. int/sites/ reliefweb. int/files/resources/The-Sustainable-Development-Goals-Report-2019_Russian.pdf (дата звернення: 30.08.2021).

\section{References:}

1. Bilorus, O. G. \& Matseiko, Yu. (2006). Hlobalnyi stalyi rozvytok [Global sustainable development]. Kyiv : KNEU [in Ukrainian].

2. Danilishin, B. M., Koretskiy, M. Kh., \& Datsiy, O.I. (2006). Investytsiina polityka $v$ Ukraini [Investment policy in Ukraine]. Donetsk : "Yugo-Vostok, LTD" [in Ukrainian].

3. Kuzmin O. Y., Prince S.V. \& Melnik L.I. (2005). Upravlinnia innovatsiinym protsesom na pidpryiemstvakh: problemy i shliakhy yikh rozviazannia [Innovation process management in enterprises: problems and ways to solve them]. Economic Bulletin of the National Technical University of Ukraine "Kyiv Polytechnic Institute", 2, 371-382 [in Ukrainian].

4. Bruntland Ed.G. (1987) Word Commission on Environment and Development «Our Common Future» Oxford : Oxford Univ. Press.

5. Osushchestvlenye reformu SR OON y ynnovatsyonnoe fynansyrovanye TsUR. Retrieved from https://www.unfpa.org/sites / default / files / admin-resource / RU_AR.pdf [in Russian].

6. Doklad o myrovykh ynvestytsyiakh, YuNKTAD. Retrieved from http://unctad.org/en/ pages/ PressRelease.aspx? OriginalVersionID=194 [in Russian].

7. Muzychenko, T. O. (2014). Investytsii ta investytsiina diialnist: poniatiinyi apparat [Investments and investment activities: conceptual apparatus]. Sustainable economic development, Issue 3, 161-167 382 [in Ukrainian].

8. Borshch, L. M. \& Herasymova, S.V. (2007). Investuvannia: teoriia i praktyka [Investing: theory and practice]. Kyiv : Znannia [in Ukrainian].

9. Hubskyi, B. V. (1997) Investytsiini protsesy v hlobalnomu seredovyshchi [Investment processes in the global environment]. Kyiv : Naukova dumka [in Ukrainian].

10. Dem'yanenko, M. Ya. (2003). Finansovyi slovnyk-dovidnyk [Financial dictionaryreference]. Kyiv : IAE UAAN [in Ukrainian].

11. Lanoviy, V. \& Dubrovsky, K. (2002). Investytsii ta rozvytok [Investment and development]. Kyiv: Center of Rinkovykh Reforms [in Ukrainian].

12. Muzichenko, A. S. (2001). Derzhavne rehuliuvannia investytsiinoi diialnosti [State regulation of investment activity]. Kyiv: Naukovy Svit [in Ukrainian].

13. Sokurenko, P. I. \& Kryshan, O. F. (2010). Investytsiina polityka yak efektyvna forma upravlinnia ukhvalenniam investytsiinykh rishen [Investment policy as an effective form of investment decision management]. European vector of economic development, 1 (8), 208-214 [in Ukrainian].

14. Martynenko, V. F. (2003). Formuvannia investytsiinoi modeli rozvytku Ukrainy: metodolohichnyi aspect [Formation of investment model of development of Ukraine: methodological aspect]. Bulletin of the Ukrainian Academy of Public Administration under the President of Ukraine, 3, 172-179 [in Ukrainian].

15. Koiuda, O. P., Lepeiko O. P., Koiuda, V. O. \& Hrynova, V. M. (2008). Investuvannia [Investing]. Kyiv : Znannia [in Ukrainian].

16. Borshch, L. M. \& Herasymova, S.V. (2007). Investuvannia: teoriia i praktyka [Investing: theory and practice]. Kyiv : Znannia [in Ukrainian]. 
17. Orobets, I.V. (2013). Praktyka vprovadzhennia kontseptsii staloho rozvytku v upravlinni pidpryiemstvamy [The practice of implementing the concept of sustainable development in enterprise management]. The formation of a market economy in Ukraine: Coll. Science. wash. Lviv: LNU I. Franko, 29(2), 43-48 [in Ukrainian].

18. Blank, Y.A. (1995). Ynvestytsyonniy menedzhment [Investment management]. Kyiv : YTEM LTD [in Ukrainian].

19. Onopriienko, O. D. (2015). Problemy ta shliakhy formuvannia spryiatlyvoho investytsiinoho klimatu v Ukraini v suchasnykh umovakh [Problems and ways of forming a favorable investment climate in Ukraine in modern conditions]. Development strategy of Ukraine, 2, 62-66 [in Ukrainian].

20. Burlaka, N.I. (2019). Rozvytok investytsiinoi diialnosti pidpryiemstv Ukrainy [Development of investment activity of Ukrainian enterprises]. Investments: practice and experience, 8, 37-44 [in Ukrainian].

21. Mykhailenko O. H. \& Krasnykova N. A. (2020). Vplyv inozemnykh investytsii na rozvytok ekonomiky Ukrainy $\mathrm{v}$ umovakh hlobalizatsii [The impact of foreign investment on the development of Ukraine's economy in the context of globalization]. Efficient economy, 7. Retrieved from http://www.economy. nayka. com. ua/ ?op=1\&z=8046 [in Ukrainian].

22. Markevych, K. (2019). Khto i yak investuie v Ukrainu [Who and how invests in Ukraine]. Retrieved from http://razumkov.org.ua/statti/khto-i-iak-investuie-v-ukrainu [in Ukrainian].

23. Zahorskyi, V.S. (2018). Kontseptualni osnovy formuvannia systemy upravlinnia stalym rozvytkom ekoloho-ekonomichnykh system [Conceptual bases of formation of management system of sustainable development of ecological and economic systems]. Lviv : LRIDU NADU [in Ukrainian].

24. Doklad Mezhpravytelstvennoho komyteta эkspertov po fynansyrovanyiu ustoichyvoho razvytyia. Retrieved from https: //www.un.org/esa/ffd/wp-content/uploads/2015/03/ICESDF_Ru.pdf [in Russian].

25. Doklad o Tseliakh v oblasty ustoichyvoho razvytyia. Retrieved from https://reliefweb. int/sites/ reliefweb. int/files/resources/The-Sustainable-Development-Goals-Report-2019_Russian.pdf [in Russian]. 